\title{
Tax Procedure Law within the Reduction of Administrative Burdens - between Goals and Praxis
}

\author{
UDK: 336.225(045) \\ Polona Kovač \\ University of Ljubljana, Faculty of Administration \\ polona.kovac@fu.uni-lj.si
}

\begin{abstract}
The Tax Procedure Act (TPA; Slovenian ZDavP) is the key law regulating relations among the participants in tax collection procedures. Therefore, it has been more or less thoroughly changed several times in recent years, also within the government's programme of reduction of administrative burdens (RAB; Slovenian $\mathrm{OAO}$ ). Procedures are being attempted to be simplified for both taxpayers and tax authorities. The paper explores a selection of institutes introduced to this end, such as tax assessment through a provisional specification, service by regular mail, advance rulings, etc. The author considers statistical data on how frequently those (new) institutes were used in 2006, 2007 and 2008 to establish whether, or how much, goals of the regulatory change in the tax procedure are actually being achieved in praxis. It is found that notwithstanding some exceptions, the majority of the considered institutes do amount to a realisation of the RAB programme.
\end{abstract}

Key words: tax procedure, law, reduction of administrative burdens.

JEL: H2O, K40, D73

\section{Overview of the tax procedure and the reduction of administrative burdens}

The paper aims to consider whether, and in what elements, the adoption or amendment of tax procedure legislation carried out within the programme of reducing administrative burdens in recent years has actually reached the set goal. We have therefore selected some institutes defined in several materials 
Polona Kovač

Tax Procedure Law within the Reduction of

Administrative Burdens - between Goals and Praxis

(primarily in Predlog ZDavP-2 ${ }^{\mathbf{1}}$ and documents relating to Slovenia's development strategy) as RAB, and went on to compare statistical data recorded by the Tax Administration of the Republic of Slovenia (TARS; Slovenian DURS) on the realisation of those institutes. ${ }^{2}$

The tax procedure is a special administrative $\mathbf{3}^{\mathbf{3}}$ procedure ensuring tax collection, i.e. the statement or assessment and payment or refund of taxes, control of tax liabilities, enforcement, and international cooperation in tax matters (Jerovšek \& Kovač, 2008; general overview in Kopp \& Ramsauer, 2003). The tax procedure is regulated by several laws. Some procedural provisions are included in the laws on particular tax types themselves; mainly the Tax Procedure Act is applied (having existed in Slovenia since 1996; more in Šinkovec, 2002; currently the TPA-2 ${ }^{4}$ is in force); subsidiarily, the tax administration and customs service laws, respectively, apply, as well as, partly, the Inspection Act (IA; Slovenian ZIN), the General Administrative Procedure Act (GAPA; Slovenian ZUP), ${ }^{5}$ and implementing regulations of those laws (general overview of subsidiarity in Androjna \& Kerševan, 2006). For the RAB as it relates to both taxpayers and tax authorities as well as others involved in tax proceedings (like banks, employers, registry institutions providing data), the key law is the Tax Procedure Act and, partly, the IA and the GAPA. The latter two have also been amended several times within the RAB. ${ }^{6}$ However,

1 Draft Tax Procedure Act-2; available at the website Slovenija jutri, EVA: 2006-1611-0024 (material for first reading, autumn 2006), and in Poročevalec Državnega zbora RS, no. 99/06 (20 September 2006).

2 Most of this data has been taken from the TARS annual work reports available at its website. Four graduate students helped the author collect and process the data within the Research Seminar course of the Faculty of Administration. I wish to express my gratitude to the TARS, particularly A. Kovač Arh and P. Jenko from the Legal Service of its General Tax Office, for their aid in collecting the data not (yet) publicly available online but judged as relevant for a consideration of the issues the paper is concerned with.

3 Tax authorities mainly conduct administrative proceedings, to which, however, expedited minor offence proceedings were added in 2005 within the tax inspection body's competences if a tax violation is legally classified as a minor offence, while tax investigations as sui generis (pre-administrative, or pre-minor-offence) proceedings were also introduced, by the TPA-2, in 2007. The administrative procedure is a point where the public and individual interests meet and are to be kept balanced and proportional (see commentary to Slovenian Constitution, Šturm et al., 2002). If a right, obligation or legal entitlement is defined as administrative in nature, the administrative procedure has to ensure that neither a public interest is excessively protected nor an individual interest has precedence (principle of protection of client rights and the public interest, Art. 7 of the General Administrative Procedure Act).

4 Published in Ur. I. RS (Official Gazette of the Republic of Slovenia), nos. 117/06, 24/08ZDDKIS, 125/08-ZDavP-2A, 20/09-ZDoh-2D.

5 Ur. I. RS, nos. 80/99, 70/00-ZUP-A, 52/02-ZUP-B, 73/04-ZUP-C, 119/05-ZUP-D, 24/06-UPB2, 105/06-ZUS-1, 126/07-ZUP-E, 65/08-ZUP-F.

6 E.g.: data exchange required from the authorities, GAPA Arts. 66 \& 139 (Androjna \& Kerševan, 2006, p. 303); abolition of the professional competence exam on the administrative procedure, GAPA Art. 31; the preventive measure of a warning, IA Art. 28 (Pirnat et al., 2004); reception of applications outside tax offices, and Saturday office hours of tax offices 
the tax procedure having a specific nature and a relatively comprehensive specific regulation (Šinkovec, 2002), all this likely only contributes to the RAB in tax proceedings to a minor extent, therefore the paper focuses on how the Tax Procedure Act has gradually been changed. A RAB programme has been carried out in Slovenian public administration for several years (especially since 2001 when the government established a committee for RAB; details on the development of the programme in Josevski, 2008). RAB-related goals and activities frequently involve regulatory measures, where Slovenia generally pursues good foreign practices (e.g. voluntary disclosure and advance ruling; more in Predlog ZDavP-2, 2006, and Jerovšek et al., 2008). As regards tax law, it has undergone change that is both substantive (e.g. new deductions, abolition of certain taxes) and, primarily, procedural in nature, since especially the way in which taxpayers' rights, obligations, and legal entitlements are realised can be made easier by simplifications for all involved (cf. Jerovšek, 2005, Kovač, 2006). Among other things, this makes taxpayers, as vital elements of the economy, better adaptable to market circumstances, and thus competitive. Some of the new arrangements aimed at procedural simplification - a key RAB goal in changing the tax procedure law in 2004-2009 - are clearly advantageous for taxpayers, while in other cases work is made easier for tax authorities although perhaps burdening the taxpayers (Jerovšek, 2005a, Kovač, 2007). The goal of RAB is to maximally disburden tax authorities and tax-paying individuals and corporations of time-consuming and costly administrative tasks bringing no added value because being doubled or not contributing to the objective of the tax procedure, i.e. the collection of tax. The tax reform, as a fairly comprehensive set of RAB-related measures mainly started in 2006 and 2007, has thus fundamentally been aimed at promoting competitiveness of the national economy and the system's integrity in relation to taxpayers and the society at large. It has pursued the general reform goals of promoting entrepreneurship and competitiveness of Slovenia as following from the Lisbon strategy, Slovenia's development strategy, and the Programme of measures of the Republic of Slovenia for the promotion of entrepreneurship and competitiveness for 2007-2013 (the Government, 2008). This is why a Tax Procedure Act indeed was drafted and passed $^{\mathbf{7}}$ in 1996 (Slovenia priorly only having had some procedural provisions in substantive laws and an immediate use of the GAPA) and thereafter more or less

(under the Decree on administrative operations; see introductory notes in Kovač et al., 2008). Saturday office hours were introduced in 2007; although tax offices were visited by no more than approx. 0.9 client per 1 employee during this time in both 2007 and 2008, this requirement was only abolished in 2009.

7 Ur. I. RS, nos. 18/96, 78/96 Skl.US: U-I-376/96, 87/97, 35/98 OdI.US: U-I-376/96-9, 82/98, 91/98, 1/99-ZNIDC, 108/99, 37/01 OdI.US: U-I-18/98-20, 97/01, 31/03 Odl.US: U-I-72/00-15, 33/03 Skl.US: U-I-108/99-14, 105/03 Odl.US: U-I-252/00-12, 16/04 Odl.US: U-I-233/01-14, 42/04 OdI.US: U-I-329/02-7. 
Polona Kovač

Tax Procedure Law within the Reduction of

Administrative Burdens - between Goals and Praxis

thoroughly changed several times. Thus there have been several laws and amending laws on whose basis several distinct periods of regulation of the tax procedure in Slovenia may be defined, as follows from Table 1.

Table 1: Tax procedure periods and (new or amending) laws

\begin{tabular}{|c|c|c|c|}
\hline No. & Period & Legal basis & $\begin{array}{c}\text { Time of being in force or } \\
\text { applied }^{8}\end{array}$ \\
\hline 1 & $\begin{array}{l}\text { Arrangement with no separate tax } \\
\text { procedure law }\end{array}$ & $\begin{array}{l}\text { Sector-specific } \\
\text { taxation laws and } \\
\text { the GAPA }\end{array}$ & Until 31 December 1996 \\
\hline 2 & $\begin{array}{l}\text { Arrangement with a (first Sloveni- } \\
\text { an) separate tax procedure law }\end{array}$ & TPA & $\begin{array}{c}1 \text { January } 1997 \text { - May } 2004 \\
\text { / } 1 \text { January } 2005\end{array}$ \\
\hline 3 & $\begin{array}{l}\text { Arrangement after Slovenia's } \\
\text { becoming a full EU member - a } \\
\text { new (second Slovenian) law }\end{array}$ & TPA-1 ${ }^{10}$ & $\begin{array}{l}1 \text { January } 2005-31 \\
\text { December } 2006 \\
\text { (partly already since May } \\
\text { 2004) }\end{array}$ \\
\hline 4 & $\begin{array}{l}\text { Arrangement after tax reform } \\
\text { measures - amending law }\end{array}$ & TPA-1B & $\begin{array}{c}1 \text { January } 2006-31 \\
\text { December } 2006\end{array}$ \\
\hline 5 & $\begin{array}{l}\text { A comprehensive arrangement of } \\
\text { the tax procedure within the tax } \\
\text { reform - a new (third Slovenian) } \\
\text { law }\end{array}$ & TPA-2 & $\begin{array}{l}\text { In force since November } \\
\text { 2006, applying since } 1 \\
\text { January } 2007\end{array}$ \\
\hline 6 & $\begin{array}{l}\text { Amendments made within the } \\
\text { economic crisis }\end{array}$ & $\begin{array}{c}\text { TPA-2A } \\
\text { PITA (Personal } \\
\text { Income Tax Act; } \\
\text { Slovenian ZDoh)-2D }\end{array}$ & $\begin{array}{l}\text { Since } 31 \text { December } 2008 \\
\text { In force since } 14 \text { March } \\
\text { 2009, applying since } \\
\text { January } 2009^{\mathbf{1 1}}\end{array}$ \\
\hline
\end{tabular}

8 Under the TPA-2 (Art. 418), laws not in force anymore are still applied for administrative matters/cases with regard to which an ordinary or extraordinary legal remedy had been filed when the TPA-2 began to apply, i.e. on 1 January 2007. In such cases the matter is concluded in accordance with the TPA-1 and, through this, possibly even in accordance with transitional and final provisions of still earlier laws if an administrative proceeding or dispute concludes with a modification or annulment of a tax decision. For the purpose of equal protection of rights (Art. 22 of the Constitution, see Šturm et al., 2002), however, the law applied in regard to substantive rules in a reopened proceeding is the one for that tax period to which the tax decision relates (except if a substantive provision of the TPA-2 is more favourable for the taxpayer, e.g. regarding the length of the period of limitation; according to Jerovšek et al., 2008).

$9 \mathrm{It}$ is appropriate to point out here that the tax procedure is the only one of the approximately $400-500$ special administrative procedures of the Slovenian legal order that is regulated by a special procedural law, other procedures being partly provided for by special procedural provisions of substantive laws and by the GAPA (Androjna \& Kerševan, 2006, Jerovšek \& Kovač, 2008).

10 Ur. I. RS, nos. 54/04, 57/04-ZDS-1, 109/04 Odl. US: U-I-356/02-14, 128/04 Odl. US U-I166/03-12, 139/04, 56/05 Skl. US U-I-159/05-4, 96/05-ZRTVS-1, 100/05 OdI. US U-I-159/05-14, 109/05, 21/06 Odl. US: U-I-32/04-10, 21/06-UPB2.

11 Under the PITA-2D, taxpayers have been allowed, regardless of Art. 54 of the PITA-2, to already apply for a reduction of their tax base for 2008 by submitting a correction of their tax statement within 30 days from when the amending law began to apply (the Act thus having had a retroactive temporal and procedural effect to taxpayers' benefit). 
In the following sections we consider selected tax procedure institutes supposedly a part of the RAB programme, by absolute data for respective years and use trends, especially for the years:

- 2006 application of TPA-1B,

- 2007-2008 - application of TPA-2, which (mainly) took over TPA-1B institutes regarding the $\mathrm{RAB}$, adding new ones.

\section{Overview of use of selected TPA-2 institutes in praxis}

\subsection{Selection of considered institutes}

In line with what we say in the introduction, the paper only considers certain legislative institutes, while it needs to be stressed that a comprehensive analysis of the tax procedure regulation and the RAB should involve different rules including those not relating to the RAB at first glance, as the totality of norms collectively results, in a complex manner, in the final outcome of non/ realisation of reform goals (Pirnat et al., 2004). TPA institutes forming a part of the RAB programme are thus not deemed to include, say, fundamental principles of the tax procedure, although some (e.g. the principle of proportionality; see Šinkovec, 2002, Kovač, 2006a), even according to European case law, fairly directly contribute to a realisation of RAB goals in particular proceedings (while some are a direct basis for certain institutes, e.g. the principle of certainty for advance ruling).

In regulating the tax procedure, particularly since 2006, the RAB has played a major role, especially the TAP-2 clearly comprising a considerable number of norms aimed at RAB, or simplification (according to Predlog ZDavP2,2006 , pp. 2-14). To be true, the RAB process is being realised in tax procedure law step by step; increasingly more RAB institutes are being introduced by new Acts and amending Acts (see Table 2). The data presented is thus relevant as a study of cases. Based on explicit statements on the RAB by the authors of the Draft TPA- $2^{\mathbf{1 2}}$ and the available TARS data, seven institutes have

12 As regards, for example, personal income tax assessment (Predlog ZDavP-2, 2006, pp. 2 $\&$ 14), deferred payment of tax (ibid., pp. 9 \& 185), service by regular mail (ibid., p. 182). Details in Jerovšek et al., 2008, commentaries to particular provisions; for the pre-filled personal income tax return cf. Klun, 2009 (e.g. the first country with a pre-filled return was Denmark in 1990). 
Polona Kovač

Tax Procedure Law within the Reduction of

Administrative Burdens - between Goals and Praxis

finally been selected (given in the order of the article(s) of the TPA-2 regulating them):

Table 2: Overview of considered RAB-related tax procedure institutes

\begin{tabular}{|c|c|c|c|}
\hline No. & Institute & Legal bases & $\begin{array}{l}\text { Time of } \\
\text { application } \\
\text { (2006-2008) }\end{array}$ \\
\hline 1 & Advance ruling & TPA-2 Art. 14 & 2007-2008 \\
\hline 2 & Voluntary disclosure & $\begin{array}{l}\text { TPA-1 Arts. 390.a \& 390.b } \\
\text { TPA-2 Art. 55, \& Arts. 63, 396, 399, and } \\
\text { others }\end{array}$ & $\begin{array}{c}2006 \\
2007-2008\end{array}$ \\
\hline 3 & $\begin{array}{l}\text { Service (by regular } \\
\text { mail) }\end{array}$ & TPA-2 Art. 85 & $2007-2008$ \\
\hline 4 & $\begin{array}{l}\text { Cancellation, deferral, } \\
\text { and phased payment of } \\
\text { tax due }\end{array}$ & $\begin{array}{l}\text { TPA-1 Arts. } 36 \& 37 \\
\text { TPA-2 Arts. } 101 \& 102 \text {; and, newly, Arts. } \\
103 \text { (special cases) \& } 105 \text { (cancellation of } \\
\text { amounts of up to EUR 1) }\end{array}$ & $\begin{array}{c}2006 \\
2007-2008\end{array}$ \\
\hline 5 & Tax investigation & TPA-2 Art. 131 & 2007-2008 \\
\hline 6 & $\begin{array}{l}\text { Notice of tax arrears to } \\
\text { be enforced }\end{array}$ & $\begin{array}{l}\text { TPA-1 Art. } 128 \\
\text { (abolished by TPA-2) }\end{array}$ & 2006 \\
\hline 7 & $\begin{array}{l}\text { Provisional specificati- } \\
\text { on in the assessment } \\
\text { of personal income tax }\end{array}$ & $\begin{array}{l}\text { TPA-2 Art. } 421 \\
\text { (pre-filled personal income tax return for } \\
2006 \text {, i.e. proceedings of 2007) } \\
\text { TPA-2 Arts. } 267 \mathrm{ff} \text {. } \\
\text { (preliminary provisional specification) }\end{array}$ & 2008 \\
\hline
\end{tabular}


Regarding these institutes, our hypothesis is that they are used with unequal frequency, but their statistical use trend should be upward if the RAB goal is to be achieved in praxis. In some cases taxpayer status is taken into account with a focus on economic operators (primarily legal entities as well as natural persons registered as autonomous economic operators), as in taxation, the RAB programme places a priority on active operation of the taxpayers vital for how the market, i.e. the economy, functions.

In addition, the TPA-2 (as well as the prior TPA-1) has a number of other provisions relating to RAB. Of key importance is the primary status of selfassessment through a tax statement as a mode of settling the tax liability (more in Jerovšek \& Kovač, 2008). A further important provision, for example, is that of Art. 50 regarding petty amounts of less than ten euros that are not assessed at all; here the proceeding is closed with an official note, as the assessed tax would not have amounted to the average costs of conducting the simple tax procedure (naturally, however, the liability is carried over into the next accounting period). Similarly, an overpaid tax is not refunded without the taxpayer's request (under Art. 97) and an enforcement proceeding is not initiated (under Art. 149) if these are amounts of less than EUR 10. Under applicable legislation, the TARS does not enforce tax liabilities for the national broadcasting service or chamber membership fees. Additional acceptable securities are provided for; the relation between submitting a tax return before or after the deadline is clearly set out; generally only documents are used as evidence in a proceeding; the burden of proof in assessing the tax base is reversed; costs of a proceeding are born according to a special clearly defined principle of success, and proportionally; a decision can only be issued in the form of a stamp; in case of non-matching figures, verification of a tax statement may be exerted by a direct payment of the difference; connections among proceedings are provided for (e.g. between verification and inspection procedures, or findings of inspections resulting in the reopening of particular proceedings; cf. Šinkovec, 2002); duration of inspection is generally limited to 6 months; time limit for filing a complaint against an inspection decision is extended to 30 days from service; a separate debt list is added as a basis for initiating a single enforcement procedure relating to several documents permitting enforcement; international cooperation in tax affairs is institutionalised, etc. (more in Jerovšek et al., 2008). 
Polona Kovač

Tax Procedure Law within the Reduction of

Administrative Burdens - between Goals and Praxis

\subsection{Advance ruling}

An advance ruling (or, literally, "binding information") is issued to a taxpayer by the main tax or customs office with regard to a future taxation to facilitate the decision of whether the expected tax, as a part of expenses compared to the expected profit, is an acceptable burden for a business transaction to be undertaken (Jerovšek et al., 2008). Advance rulings were introduced in 2007 as an application of the principle of certainty, although in terms of procedure, a range of reservation clauses strongly limits the planned positive effect of the institute (e.g. the time limit for the issue being no less than 6 months; more in Kovač, 2006). The institute is supposed to be primarily relevant for legal entities, especially foreign investors, with regard to the actual application of tax legislation (Predlog ZDavP-2, 2006, p. 168). According to the TARS, the purpose of this institute has been largely misunderstood in practice, as it is not uncommon that under Art. 14 of the TPA-2, taxpayers in fact request information on transactions or events already implemented or apply for a general explication of the law. Contrary to this, an advance ruling is conceived of as an act that is abstract (relating to legal situations not yet existing) and at the same time individual (relating to a specific addressee or object of taxation).

Table 3: Data on advance rulings, 2007 and 2008

\begin{tabular}{|l|c|c|}
\hline & 2007 & 2008 \\
\hline Number of requests for an advance ruling & 14 & 7 \\
\hline Number of issued advance rulings & $2^{*}$ & $3^{*}$ \\
\hline
\end{tabular}

* In both years one ruling related to value added tax and the rest to corporate income tax.

11 of the 14 requests in 2007, and 6 of the 7 in 2008, were submitted by a PLC or LTD. LTDs submitted $57 \%$ of all requests in both years. Advance rulings have not (yet) began to function in Slovenia - even requests that are submitted are not even procedurally adequate, and their chronological frequency trend has been negative. However, as regards the type of tax and applicants' status, advance rulings do seem to be relevant for rather large corporations or transactions, with some of them misinterpreting the tax authority's 
work as tax consulting service (this is probably why more requests were submitted by LTDs than PLCs, for instance). Given the number of taxable economic operators according to the Business Register (approx. 84,000 legal entities and 78,000 individuals), we may conclude that the advance ruling is not achieving the set goals. In view of the fact that in the Netherlands, for example, the provision of advance rulings is a matter of how a tax authority is organised rather than materia legis, it is likely right to conclude that the Slovenian law is too bureaucratised in this respect.

\subsection{Voluntary disclosure}

The institute of voluntary disclosure (literally "self-report") was introduced in 2006 by the TPA-1B, and improved in substance and form (by a separation into a procedural and penal part and a determination of the sequence after reinstatement) by the TPA-2. Voluntary disclosure is admissible for corporations and individuals after the deadline for submitting a tax (or withholding tax) return has expired, with the taxpayer immediately paying the tax owed (Pred$\log$ ZDavP-2, 2006, p. 176). This institute is supposed to result in positive effects for both the public interest (with tax being collected that otherwise would probably not have been) and the taxpayer, who/which does pay the tax as well as late-payment and penal interest, but is not prosecuted if submitting the disclosure before non-compliance is detected by the tax authority (cf. Jerovšek, 2005a) - voluntary disclosure only being possible until a tax assessment decision has been issued or an inspection (administrative) ${ }^{13}$ or minoroffence or criminal proceeding against the taxpayer has started. The institute is a practical application of the principles of substantive truth and settlement of tax liabilities (through a combination of sanctions according to Silvani \& Baer, 1997, pp. 11, 25), although according to some authors, it interferes, through penal liability, with the constitutional privilege against self-incrimination, so that the TPA-2 ought to be more clearly formulated (Ferlinc, 2009).

\footnotetext{
${ }^{13}$ Under the TPA-2, voluntary disclosure is admissible until the decision on the start of inspection has been served. Priorly, it was disputable at what moment inspection started, since the taxpayer was allowed to submit a voluntary disclosure in 2006 after receiving the notice of an inspection proceeding, which destructed the very purpose of inspection (cf. Jerovšek et al., 2008). Within the fundamental principles of the TPA-2, tax offices may (while not being obliged to) notify taxpayers of planned inspections by telephone or an ordinary emessage to (legally) promote disclosures and decrease the inspections needed.
} 
Polona Kovač

Tax Procedure Law within the Reduction of

Administrative Burdens - between Goals and Praxis

Table 4: Number and value of voluntary disclosures by type of tax, 2006-2008

\begin{tabular}{|c|c|c|c|c|c|c|}
\hline & \multicolumn{2}{|c|}{2006} & \multicolumn{2}{|c|}{2007} & \multicolumn{2}{|c|}{2008} \\
\hline Type of tax & 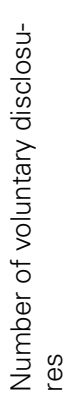 & 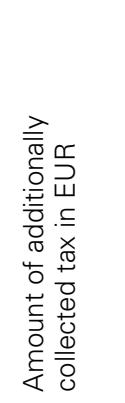 & 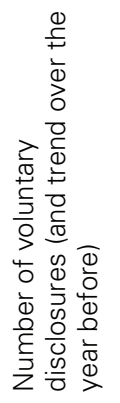 & 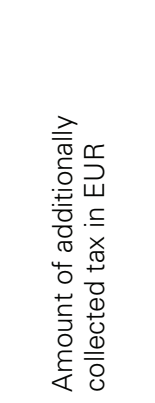 & 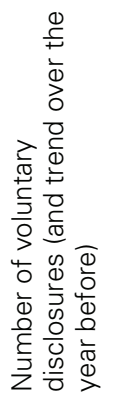 & 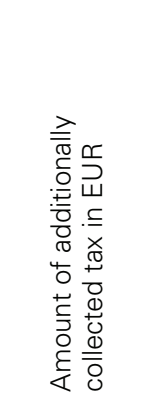 \\
\hline $\begin{array}{l}\text { Individual income taxes } \\
\text { and contributions }\end{array}$ & 10 & 101,202 & $\begin{array}{c}\uparrow \\
368\end{array}$ & $1,295,468.38$ & $\begin{array}{c}\uparrow \\
426\end{array}$ & $870,372.06$ \\
\hline Personal income tax & 425 & 165,957 & $\begin{array}{c}\uparrow \\
3,188\end{array}$ & $364,478.24$ & $\stackrel{\downarrow}{1,089}$ & $163,962.85$ \\
\hline $\begin{array}{l}\text { Personal income tax } \\
\text { prepayment }\end{array}$ & 17 & 25,914 & $\begin{array}{c}\uparrow \\
794\end{array}$ & $124,637.00$ & $\begin{array}{c}\uparrow \\
1,211\end{array}$ & $176,689.31$ \\
\hline Corporate income tax & 31 & $2,084,645$ & $\begin{array}{c}\uparrow \\
161\end{array}$ & $3,529,711,72$ & $\begin{array}{c}\downarrow \\
122\end{array}$ & $5,495,619.59$ \\
\hline VAT & 8 & 381,956 & $\begin{array}{c}\uparrow \\
103\end{array}$ & $2,094,735.79$ & $\begin{array}{c}\uparrow \\
309\end{array}$ & $1,974,054.74$ \\
\hline Other duties & 0 & 0 & $\begin{array}{c}\uparrow \\
3,948\end{array}$ & $598,654.95$ & $\begin{array}{c}\downarrow \\
656\end{array}$ & $400,183.74$ \\
\hline Tax from capital gains & 0 & 0 & 0 & 0.00 & $\begin{array}{c}\uparrow \\
5,239\end{array}$ & $918,253.60$ \\
\hline $\begin{array}{l}\text { Performance of interna- } \\
\text { tional treaties }\end{array}$ & 0 & 0 & 0 & 0.00 & $\begin{array}{l}\uparrow \\
1\end{array}$ & 488.45 \\
\hline TOTAL & 491 & $2,759,674$ & 8,562 & $8,007,686.44$ & 9,053 & $9,999,624.34$ \\
\hline
\end{tabular}

As regards the type of tax, voluntary disclosures were the most numerous in personal income tax in 2006, other duties (primarily membership fees 3,948 -, followed by tax on the disposal of real property, inheritance tax, etc.) in 2007, and tax from capital gains (primarily from interest $-4,022$ out of 5,239 ) and, newly, international enforcements in 2008; the amount collected being, as expected, disproportional with the number of disclosures, as certain taxes, by 
nature, are more voluminous than others. The most substantive yield from voluntary disclosures in all years is thus attributable to corporate income tax, having increased from approx. EUR 2 million in 2006 to 5.5 million two years later. According to all indicators, both the number of voluntary disclosures and the amount of duties collected on their basis were definitely increasing in 2006-2008, but their structure is changing. Taxpayers evidently need time to process new legislative arrangements, which, for example, is reflected in the remarkable increase in voluntary disclosures from 2006 (around 500) to 2007 (already over 8,500); a similar observation applies, for instance, for the subsegment of sole trader personal income tax prepayments (from 17 to 794 and to 1,211 in 2006-2008):

\section{Figure 1: Number of voluntary disclosures relating to personal income tax prepayment, 2006-2008}

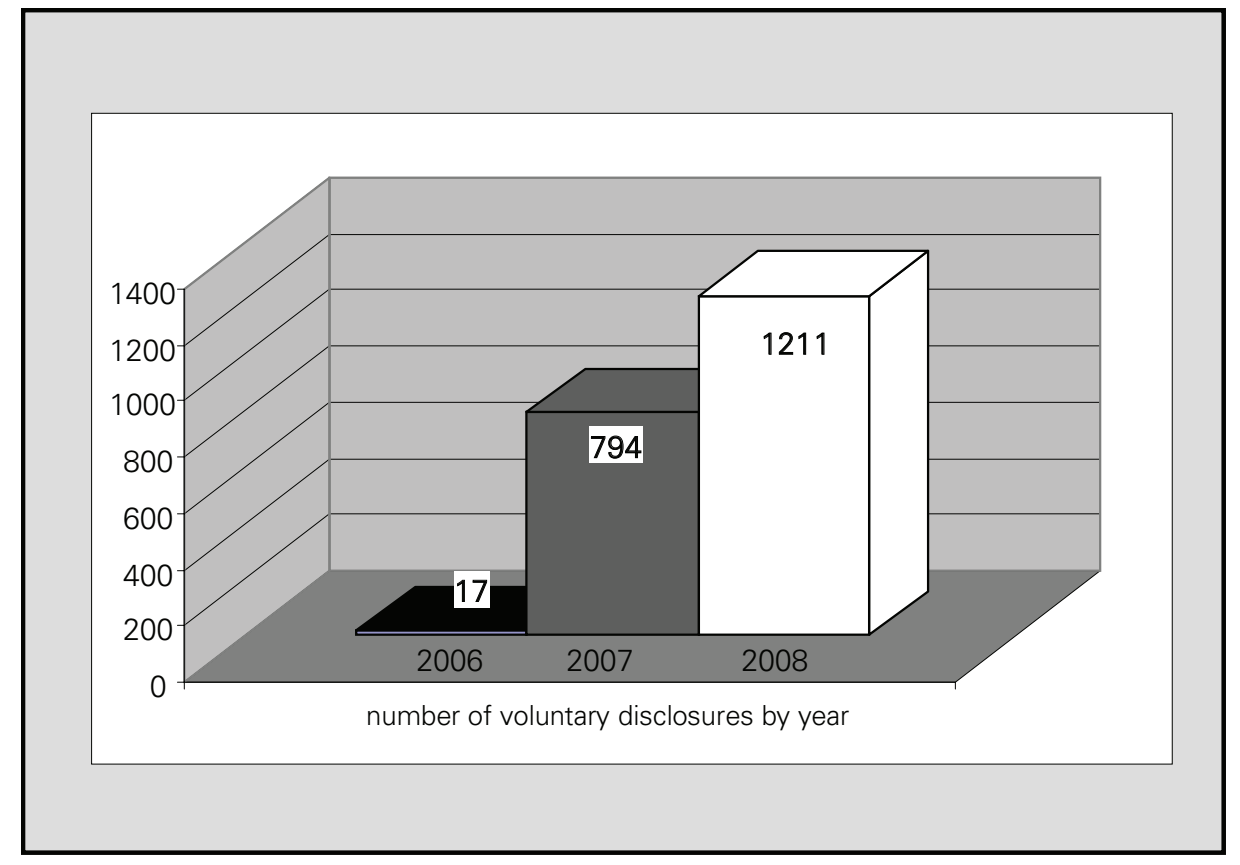

On the other hand, in certain taxes voluntary disclosures are decreasing in number, which in the case of personal income tax (by almost three times from 2007 to 2008) is definitely the combined result of the newly introduced preliminary data verification followed by a provisional tax specification as a prefilled tax return; a similar observation applies for other duties. Given the new 
Polona Kovač

Tax Procedure Law within the Reduction of

Administrative Burdens - between Goals and Praxis

sources it is clear that a further stabilisation of the number of voluntary disclosures and their structure by tax type is to be expected in the future.

In total, nearly 21 million euros were collected in three years on account of voluntary disclosures. To quantify the institute's benefits, at least the costs of non-initiated inspections should be added to this amount, indicating that this institute as such is to be preserved, though perhaps slightly technically improved. It is impossible, however, to measure out the positive effect of the significantly higher level of tax culture undoubtedly ensuing when liabilities are settled voluntarily.

\subsection{Service by regular mail}

Unlike Art. 87 of the GAPA, the TPA-2 introduced in 2007 service by regular mail (slightly adapted with regard to the GAPA because of the fiction of effected service) as sufficient for most written communications in the tax procedure with a declared goal of savings made on account of the costs of delivery to addressee only. Despite the possible reserve as to such arrangement being non-constitutional in relation to the GAPA (see Kovač, 2008), the data is so encouraging for the TARS that preparations are taking place in 2009 for an even broader application of the institute. ${ }^{\mathbf{1 4}}$ The calculated payment date thus roughly equals the sum of chronologic events: dispatch of the relevant act, 20 days for start of fiction of effected service, and a further 30 days from the service for enforceability, i.e. the payment of tax (general time limit for voluntary performance). Here the order of payments needs to be taken into account (by the order of becoming due for taxes specified on the payment instrument). Fiction of effected service, however, is just as important for filing legal remedies as it is for the payment deadline and enforcement, and the TARS, with a view to a more undisputable calculation of the relevant date, has therefore started to indicate the date of dispatch on the envelope (if these are centrally printed decisions or a dispatch in instalments, it is simply the outsourced contractor that prints the date).

14 The Act provides: "All decisions and orders and other documents from whose service a time limit begins to run except for decisions, orders and other documents issued in a tax control or tax enforcement proceeding, shall be served by regular mail. Service shall be deemed effected on the 20th day from the day of dispatch ..." Service by regular mail was slightly limited at the end of 2008 by the TPA-2A, under which delivery to addressee only is also mandatory for decisions on phased payment of tax. 
To quantify savings resulting from the shift from delivery to addressee only to regular mail delivery, we have compared the decisions issued for personal income tax (over 1.1 million annually), residential land use fee (approx. 0.7 million annually), tax on the disposal of real property, and income tax from property, interest, and capital gains in 2006 (i.e. when the TPA-2 had not yet applied), and in 2007 and 2008. The number of decisions has largely remained the same (about 2 million annually), while the difference in the costs of their service has been no less than approx. 2-3 million euros annually:

Table 5: Costs of service, and savings on account of service by regular mail, 2006-2008 in EUR

\begin{tabular}{|c|c|c|c|c|c|c|}
\hline ֻे & 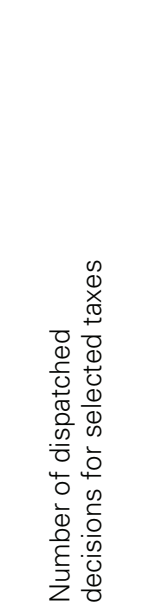 & 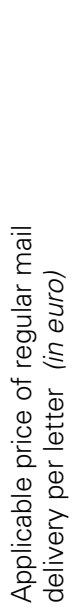 & 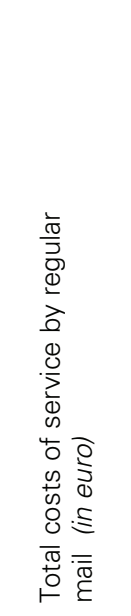 & 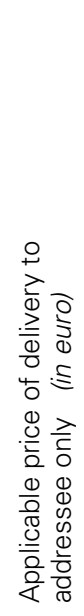 & 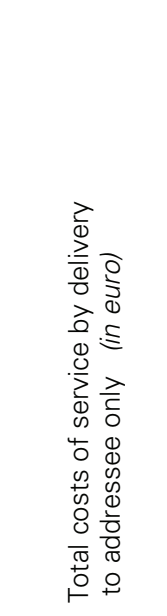 & 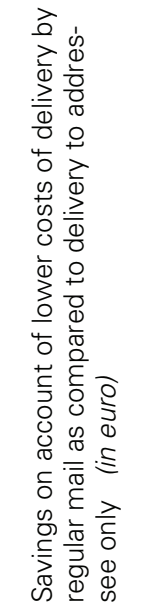 \\
\hline 2006 & $2,124,866$ & 0.24 & $509,967^{*}$ & 1.73 & $3,676,018$ & $3,166,051 *$ \\
\hline 2007 & $2,012,670$ & 0.25 & 503,167 & 1.78 & $3,582,552^{*}$ & $3,079,385$ \\
\hline 2008 & $2,013,327$ & 0.26 & 523,465 & 1.83 & $3,684,388^{*}$ & $3,160,923$ \\
\hline
\end{tabular}

*Figure calculated for the case such service had been required by law.

These savings are somewhat reduced by the cost of serving acts that nevertheless have to be delivered to addressee only under Art. 85 of the TPA-2 because the taxpayer has not settled the liability in due time after the fictional service (because either not having received the letter or having thus deliberately extended the time in which the liability can be settled without sanctions). 
Polona Kovač

Tax Procedure Law within the Reduction of

Administrative Burdens - between Goals and Praxis

The number of such cases is not monitored, but the assessment based on practical experience is somewhere around $5-10 \%$ of cases. OECD finds that taxpayers whose non-compliance is non-deliberate account for approx. 70\% (67\% in Denmark; according to Klun, 2009) so that the specified amount of savings is evidently notably smaller in reality. This is directly confirmed primarily by the competent enforcement staff asserting that enforcements have enormously increased in number in 2009 over the years when the relevant documents had not yet been delivered by regular mail (while empirical data on an annual basis has not yet been collected). Anyhow, in the 2,013,327 decisions issued for 2008, the costs of service would thus be EUR 523,465 for service by regular mail plus an additional EUR 1,105,317, i.e. (only?) EUR $2,055,606$ in total. As we can see, the amount of savings is still considerable, especially as administrative costs are not being covered on account of collected tax with this money; still, compared with costs of enforcement proceedings, a benefit-cost comparison most likely yields a negative result.

\subsection{Cancellation, deferral, and phased payment of tax due}

Compared to the basic text of the Act, the TPA-1B extended the term of deferred or phased payment of a tax due from one to two years, allowing a cancellation, deferral, or phased payment to be granted by discretion to individuals facing a threat to their and their dependants' subsistence or, on the other hand, a deferral or instalments for legal entities or sole traders or other natural persons engaged in a registered activity if major economic damage would occur in case of timely payment (Jerovšek et al., 2008). However, a deferral or instalments cannot be granted for prepayments, tax withdrawals and certain taxes which, indeed, is technically arguable, as criteria of types of taxes and modes of meeting the obligation are being mixed in defining exceptions (according to Kovač, 2006; similarly according to Hren, 2009; differently according to Predlog ZDavP-2, 2006, p. 185). The TPA-2 brought further significant new arrangements relating to the RAB, such as the special case of deferred or phased payment if a taxpayer submits a security or gives assent to the entry of a lien in the register but, because no criteria are required to be met, only for up to 12 months (Art. 103). Further, a natural person not engaged in a registered activity is entitled to apply for three monthly instalments without having to submit a security or meet the conditions and criteria laid down in Art. 101. Although interest runs during the term of deferred or phased pay- 
Polona Kovač

Tax Procedure Law within the Reduction of Administrative Burdens - between Goals and Praxis

ment, it is only at the interbank interest rate for loans up to one year in order to preserve the real value of the debt (Jerovšek \& Kovač, 2008). All those changes have been envisaged to result in more obligations met in accordance with the principle of legality, and therefore in fewer enforcement proceedings and, primarily, fewer negative outcomes for taxpayers on the personal and business levels. The TARS data for 2004-2008, however, does not substantiate this assumption, indicating no particular increase in taxpayer applications for cancellation despite increasingly more favourable legislative conditions.

Table 6: Number of cancellations, deferrals, and phased payments, 2004-2008

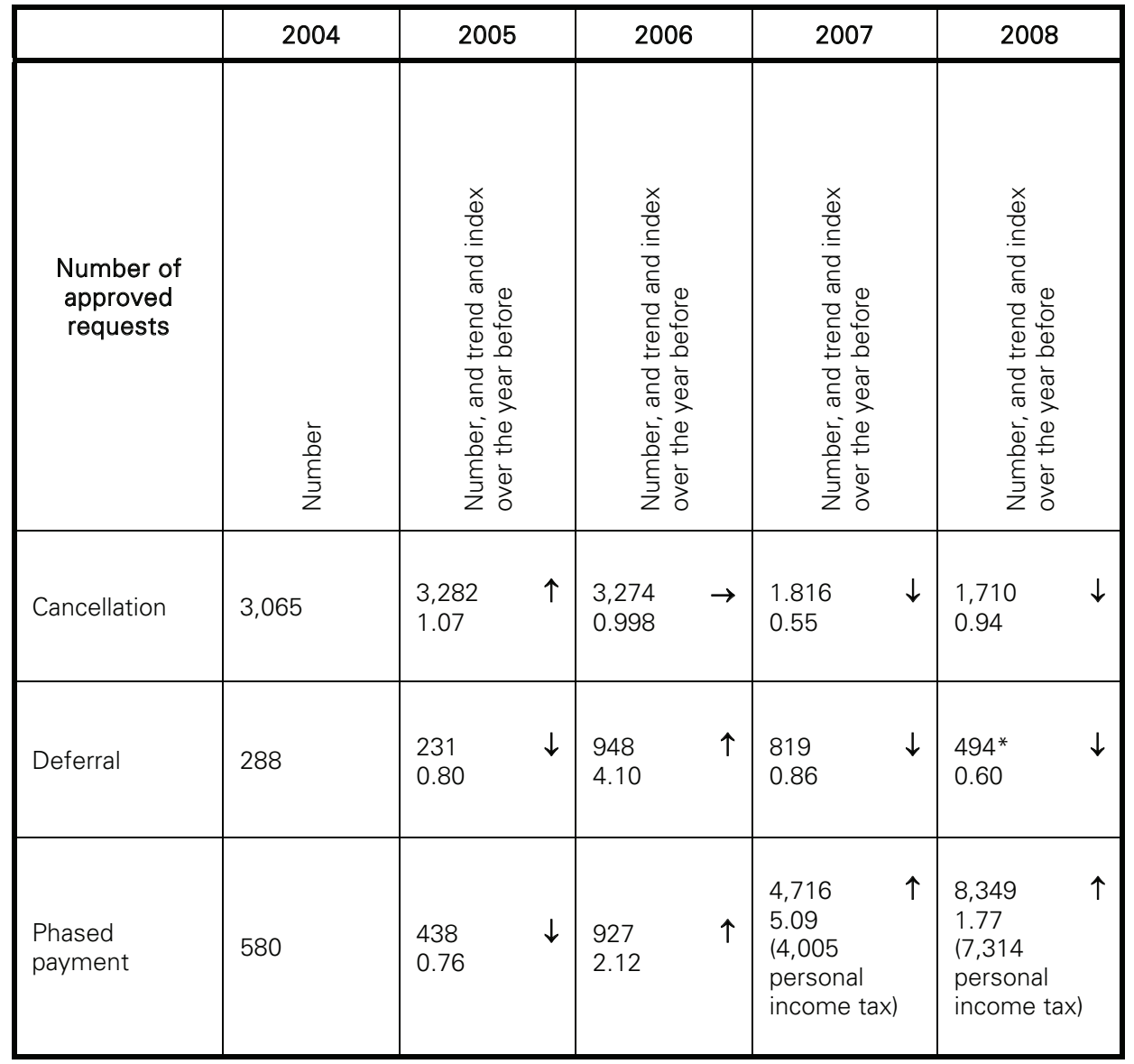

* 494 out of 1181 filed requests approved. This amounts to approx. 10 million euros (cf. to 1,120 million euros of collected income tax in 2007; according to Hren, 2009). 


\section{Polona Kovač}

Tax Procedure Law within the Reduction of

Administrative Burdens - between Goals and Praxis

It is clear from the table that phased payment is the most currently relevant institute, especially in 2007-2008 as the time marked by an economic crisis (cf. Figure 2), while cancellation and deferral have been notably decreasing (with a remarkable increase of deferrals and phased payments in 2006, attributable to the longer term under the TPA-1B). As for the type of tax, personal income tax has been the most present one throughout the period (as well as social security contributions, general sales tax, and residential land use fee). Personal income tax has predominated primarily in cancellation (generally non-admissible for legal entities) and phased payment in the past two years since the TPA-2 began to apply.

Figure 2: Number of granted requests for phased payment of tax, 2004-2008

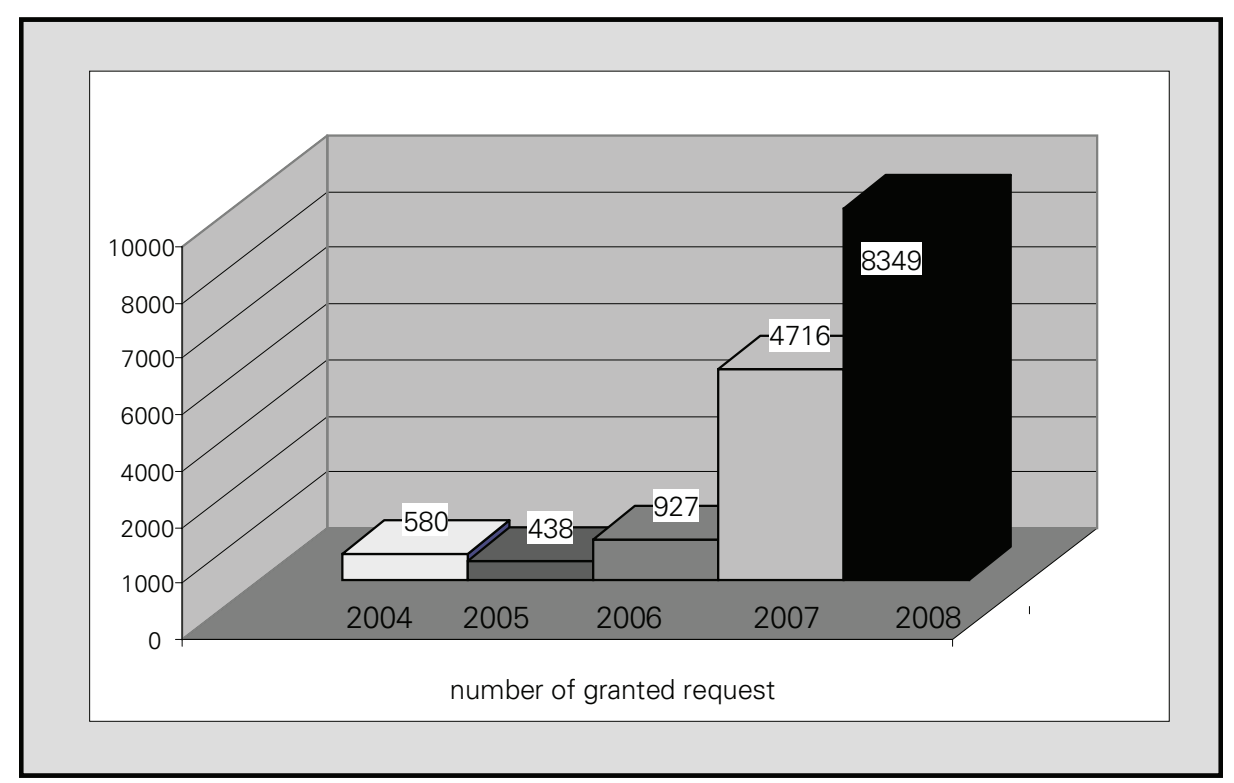

The increase in phased payment is undoubtedly attributable to the second paragraph of Art. 103 of the TPA-2, which has proved to be exceptionally currently relevant in the present social situation. This is true for all considered institutes in the light of seeking shared interests of taxpayers (social capability despite a tax liability) and tax authorities (preference of voluntary performance to avoid the need for compulsory control and enforcement). More precisely, there were approx. 4.2 million euros of cancelled taxes, 10 million euros of deferred taxes, and no less than 31.5 million euros of taxes to be paid in instalments granted in 2008 (the figures for the preceding year being approx. 7 
(cancellation), 6 (deferral) and 17 (instalments) million euros). We can conclude that the legislator reached out to taxpayers (regretfully) in view of the global crisis even before due time. This is reflected in data for 2009, indicating an almost 50\% increase in requests for a phased payment, totalling 1,300 in only the first two months compared to approx. 850 requests submitted in the corresponding period of last year (according to Hren, 2009). When the crisis expectedly eases, the institute will still be needed and should therefore be preserved; perhaps even the procedure of realising it, if not the very conditions under Arts. 101 and 102 of the TPA-2, might be simplified.

Further, from 2007 on, a tax liability by particular tax type having totalled less than EUR 1 at the end of the calendar year is automatically cancelled in February (TPA-2 Art. 105), as such liability does not even amount to $5 \%$ of the average enforcement proceeding costs (cf. Jerovšek, 2005). The institute of cancellation, or account balancing, is proving to also contribute to the transparency of tax records, especially if the objective element of a debt's weight is taken into account (as it is under the TPA-2, e.g. also in the determination of persons liable to control; cf. Jerovšek et al., 2008). This is evident primarily if considering the folowing data: from year 2006 to 2008

Figure 3: Tax cancelled on account of the amount owed with regard to taxpayer status, 2006-2008 in EUR

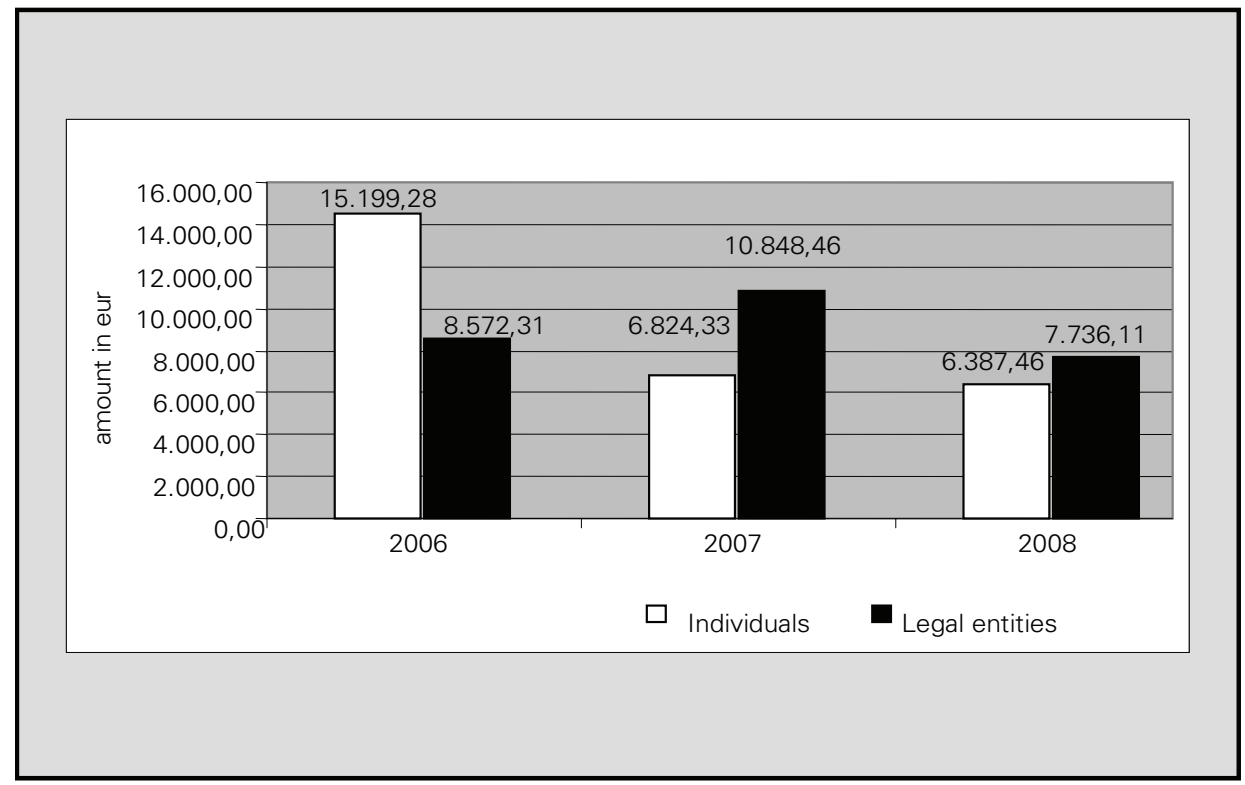


Polona Kovač

Tax Procedure Law within the Reduction of

Administrative Burdens - between Goals and Praxis

By cancelling petty amounts of tax due, tax authorities do not have to keep records for numerous taxpayers whose debt of less than EUR 1 had became due in the preceding year. This institute definitely pursues measures of reducing administrative burdens primarily for tax authorities and taxpayers, although the common budget suffers a certain loss. This loss, however, is negligible compared to the costs of record-keeping and assessment, control and, especially, enforcement proceedings, therefore it is sensible, de lege ferenda, to make the said institute even more currently relevant (upon priorly calculating the consequences) by raising the census to up to 10 euros (with regard to the intra legem analogy), especially because it aids socially very weak taxpayers.

\subsection{Tax investigation}

Tax investigation is an institute newly introduced into the tax procedure law in 2007 (priorly only in the tax administration law), as an attempt to enable tax authorities to exert control over what generally are major violations or groups of persons active in transnational structures (Predlog ZDavP-2, 2006, p. 190), i.e. when traditional inspection methods fail. It is a type of preadministrative procedure, as in case that suspicion proves to be grounded, an inspection proceeding starts and evidence from the investigation is used in this proceeding, the RAB aspect of the institute seeming to be tax authorities' greater efficiency and, ultimately, protected business partners of the taxpayer concerned, while the taxpayers themselves are primarily protected through the IA and the GAPA (Androjna \& Kerševan, 2006). The institute may be disputable in terms of the system (Kovač, 2006), as despite the prosecutory function involved, the decision on the start and object of investigation is not even served on the taxpayer but only has the role of the tax authority's internal act in relation to the inspector-investigator, while the taxpayer (only) has the chance to give a statement when/if an inspection proceeding is initiated (cf. Šinkovec, 2002).

The collected data clearly indicates (Figure 4) that the institute already became established in practice in 2007 (with a total of 358 reports, and 224 inspections conducted on the basis of what was found in investigations), and equally in 2008 (397 reports and 188 inspections; 
Tax Procedure Law within the Reduction of Administrative Burdens - between Goals and Praxis

a minor decrease here - index 0.84 over 2007). By report mode, anonymous reports predominate, accounting for approx. 60-70\%. ${ }^{\mathbf{1 5}}$

Figure 4: Number of reports for a tax investigation by receipt mode, 2007 and 2008

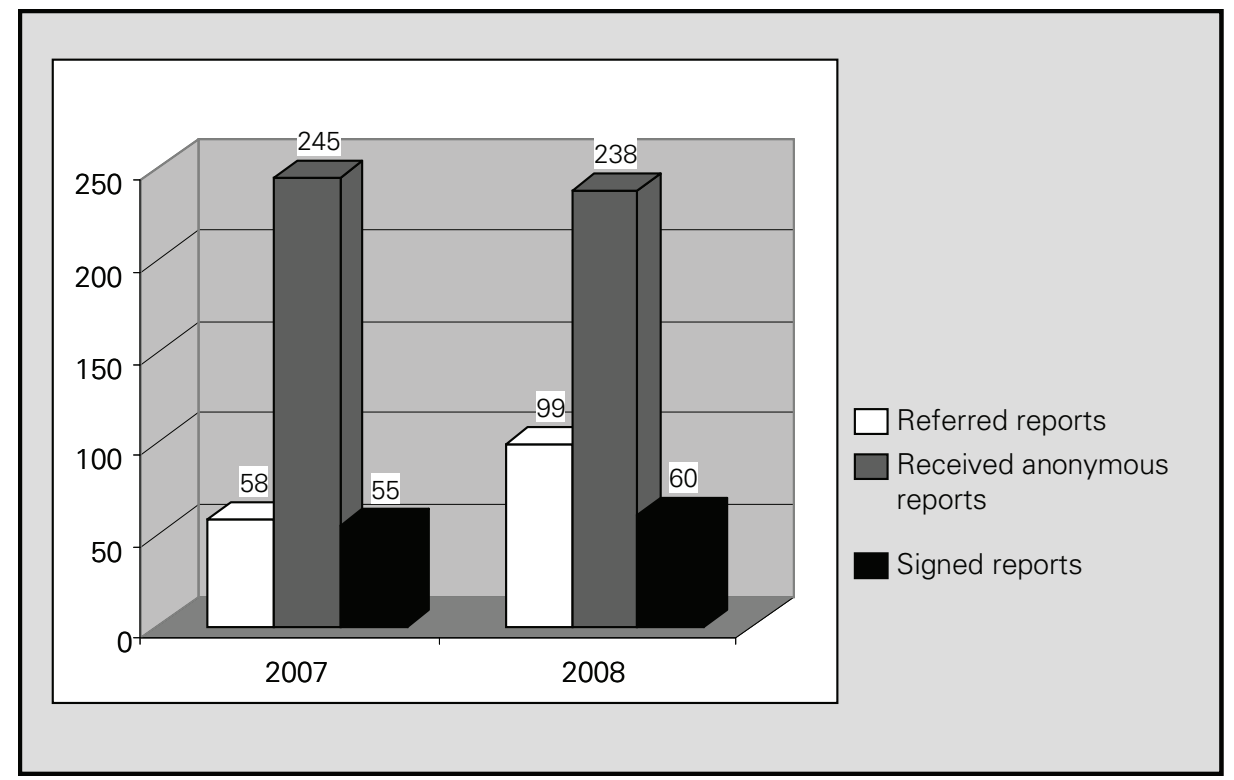

According to the TARS report for 2007, activities of the competent investigation and analysis department were mainly focused on detecting tax frauds in the sales of oil derivatives ( 29 so-called missing trade companies ${ }^{16}$ detected) and motor vehicles (12 investigations), loan industry (15 investigations), and pub and restaurant industry. The report is most frequently made by a natural person, in 2008 mainly an employee reporting their employer in relation to illegal work (especially in construction), cash withdrawals by legal entities' responsible persons, and the non-issue of invoices. As expected in view of the higher value of their debts by tax types, legal persons predominate among

15 In addition to those reports, a 24-hour free telephone line has been available since April 2007 , through which a considerable number of reports are made 606 in 2007, and a further $23 \%$ more in 2008), of which, however, only $12-15 \%$ (90 out of 606 , or 93 out of 744 ) are useful ones resulting in a collected tax.

16 The application "Red Dot" was launched in April 2009 for the detection and prosecution of those persons, based on the finding that certain persons keep appearing as "missing traders". It is used in the work of inspectors, investigators, and clerks covering VAT registration; according to the TARS 2008 report, 452 taxpayers had been entered into the system by 30 June 2008. 
Polona Kovač

Tax Procedure Law within the Reduction of

Administrative Burdens - between Goals and Praxis

those reported; in 2008 , there were 179 , i.e. $45 \%$, or, together with sole traders, $73 \%$ (another 111 of sole traders out of the 397 reported).

In total, inspections conducted on the basis of investigations yielded approx. 18.5 million (VAT approx. 7 million) euros in 2007, and approx. 9.28 million euros in 2008. The calculated average yield of a concluded inspection proceeding is approx. 67,300 euros (with the index, however, having decreased to 0.6 in 2008 over the year before). Moreover, budget revenue from certain minor offence fines is to be added to this.

\subsection{Notice of tax arrears to be enforced}

With the purpose of friendliness (critically discussed in Jerovšek, 2005), the legislator introduced through the TPA-1 the notice of tax arrears as a condition for beginning an enforcement proceeding. The debtor had an 8-day time limit from the notice (delivered to addressee only) to pay the debt to avoid the initiation of enforcement. In praxis, this was very costly for the state (due to both administrative work and the non-realised inflow of outstanding taxes, with enforcement not having even started yet), while enabling the taxpayer to efficiently delay enforcement (for up to 73 days, as calculated by Jerovšek, ibid.). Therefore, Art. 128 was already amended in 2006 by the TPA-1B which, within $R A B$, no more required that the notice should be delivered to addressee only (cf. Predlog ZdavP-1B, 2005).

For RAB purposes, provisions on the notice of tax arrears were cancelled in full by the TPA-2; here, however, the question arises of whether this institute, given the amount of taxes collected on its basis, indeed (only) was an administrative burden. Tax authorities find the opposite, and on account of the practically established share of more or less compliant taxpayers that may delay payment but not at the cost of enforcement they, despite the lack of any direct legal basis in the TPA-2, keep sending notices to debtors, especially so because of regular mail service under Art. 85 of the TPA-2. Here growth trends are even more favourable by the collected amount than the number of proceedings itself (data taken from the TARS annual reports). ${ }^{\mathbf{7}}$

17 Additionally, there is some yield on account of the order of payments, since a taxpayer's debts are stated in accordance with the date of becoming due while a statement for a remaining debt is not served (to addressee only) again but the taxpayer is notified thereof and required to make the payment. If they thereafter confirm that they have received the relevant decision and/or that they will comply with it, it is deemed that the decision has been received. A further fact speaking in favour of preserving the institute is that it is primarily sensible 
Tax Procedure Law within the Reduction of Administrative Burdens - between Goals and Praxis

Table 7: Number of delivered notices of tax arrears to be enforced, and amount of payments made, 2005-2008

\begin{tabular}{|c|c|c|c|c|c|c|c|}
\hline & 2005 & $\begin{array}{l}2006 \text { / trend over } \\
\text { the year before }\end{array}$ & & $\begin{array}{c}2007 \text { / trend } \\
\text { over the year } \\
\text { before }\end{array}$ & & $\begin{array}{c}2008 / \text { tren } \\
\text { over the ye } \\
\text { before }\end{array}$ & \\
\hline $\begin{array}{l}\text { Number of } \\
\text { notices }\end{array}$ & 349,213 & $\begin{array}{l}437,355 \\
1.25\end{array}$ & $\uparrow$ & $\begin{array}{l}307,468 \\
0.70\end{array}$ & $\downarrow$ & $\begin{array}{l}333,473 \\
1.08\end{array}$ & $\uparrow$ \\
\hline $\begin{array}{l}\text { Amount paid } \\
\text { after the } \\
\text { notice in EUR }\end{array}$ & * 705,846,269 & $\begin{array}{l}* 986,614,355 \\
1.40\end{array}$ & $\uparrow$ & $\begin{array}{l}570,252,913 \\
0.58\end{array}$ & $\downarrow$ & $\begin{array}{l}690,279,812 \\
1.21\end{array}$ & $\uparrow$ \\
\hline
\end{tabular}

*This amount has to be reduced by costs of delivery to addressee only (in 2006, the difference in costs between such delivery (EUR 1.73 per notice) and regular mail delivery totalled EUR 651,659).

The case of notice of arrears is interesting because it sheds light on several dimensions of legal regulation of the tax procedure and functioning of the TARS. First, tax authorities can function - especially to protect taxpayers' rights while not endangering the public interest - directly by the fundamental principles rather than only by explicit rules. Further, some rules that, even in the unanimous opinion of expert scholars, seemed to be a typical administrative burden at first glance in fact bring very positive effects, even in the financial volume, let alone in the accommodation of all involved. Legislative change of 2006 and 2007 thus primarily resulted in reduced costs of mailing the notices but not an extinction of the institute. Third, in the implementation of rules and the assessment of whether they are administrative burdens, each should be regarded in the context of the combined effect of an entire law and an authority's work organisation.

to dispatch a notice in cases of minor tax arrears, as immediate enforcement would entail additional enforcement and bank ( 20 and approx. 35, respectively) costs for the debtor. 
Polona Kovač

Tax Procedure Law within the Reduction of

Administrative Burdens - between Goals and Praxis

\subsection{Provisional specification in the assessment of personal income tax}

As regards reduction of administrative burdens, the greatest contribution of the new TPA-2, in practical terms, is supposedly the principle of assessing personal income tax through a preliminary provisional specification with a mixed nature of a statement (which, as a pre-filled return, was already sent by 30 April, under Art. 421 of the TPA-2 - in 2007) and an administrative decision (since 2008), provided that no protest is filed (TPA-2 Arts. $267 \mathrm{ff}$.; cf. Jerovšek, 2005a, Predlog ZDavP-2, 2006, p. 14). The TPA-2 provides that from 2008 on the tax authority, based on a preliminary internal verification of data for the past year that income payers and/or property registers submit by 31 January, prepares by 31 May a provisional personal income tax specification, which has the status of both a statement (to ensure harmony with the general part of the law and, primarily, that the taxpayer assumes responsibility for the truthfulness, correctness and completeness of the data) and a draft assessment decision which, upon the expiry of the time limit for a protest, if the latter is not filed, becomes a document permitting enforcement. If a protest is filed, an assessment decision is issued by October, and a decision also ensues if a return is filed by 30 June because a certain taxable person had not received a provisional specification.

There were only approx. 43,000 personal income tax returns filed directly by taxpayers for 2007 , and 33,838 for 2008 , as compared to $1,276,860$ in 2005 , or 1,135,422 in 2006 (with the TARS recording a total of approx. 1.012-1.275 million acts with the legal nature of an administrative decision in all those years). The described solution is advantageous to both taxpayers, who are generally relieved of preparing a return if their payers send correct data to the TARS, and tax authorities, since first-instance posterior verification has turned into a preliminary one while there are substantially fewer protests and, especially, complaints (the same according to the OECD data on pre-filled returns; Kovač, 2006a, Klun, 2009), and the payment (or refund) deadline is very likely earlier. In 2008 and 2009, for example, no less than approx. 470,000 provisional specifications for the year before became enforceable on 6 May, i.e. even before the deadline for preparing the specification. It is thus expected that approx. $46 \%$ of all personal income taxpayers already pay their liability (or are refunded) in June, while in 2005 and 2006 the first decisions were issued late in May or even in the second half of June. Further, it is important to note that each year until 2006, the TARS also employed students for entering income tax returns into the 
appropriate software and exercising posterior verification, which has for the most part ceased within the present organisation. Tax officers themselves are able to concentrate (more) on the substantive aspect of control rather than operational entries. Additional savings occur because provisional specifications are served by regular mail.

According to the TARS 2007 annual report data, the predominant share of protests filed against provisional specifications - no less than three-quarters, i.e. $76.64 \%$ - in 2007 resulted from taxpayers' own "mistakes" of not having submitted on time data on their dependants so that the deduction would be specified by the TARS in accordance with the parents' request. In relation to the first instalment of issued specifications (or pre-filled returns in 2007; totalling over half a million on 31 March), only $7.3 \%$ of taxpayers filed a protest in 2007 , and even only 4.3\% (22,408 out of the total of 518,973) in 2008 (probably because having gained experience with reporting their dependants in 2007). The trend has thus been in line with the institute's goals, and notably positive in 2007-2008. The tax authority has proved an efficient servicing institution while the institute of preliminary provisional specification itself, with its legal status of a document permitting enforcement rather than just a pre-filled return, characterises the regulation of the personal income tax procedure in Slovenia as one of the most modern and efficient in the world (cf. Kopp, 2003, Klun, 2009).

\section{Conclusions}

In summary it may be concluded that the majority of the considered institutes incorporated into the tax procedure law in 2006 or 2007 for RAB purposes, do realise the set goals, i.e. simplified procedures for taxpayers and tax authorities. This can be confirmed by the recorded frequency of their use as well as the calculated savings, but it needs to be added that it does not apply for all the institutes. As regards both the tax procedure and, more broadly, regulation within the $R A B$, it is quite commonly not fully taken into account that operationalisation of the user focus principle - because of the principles of economy and efficiency of public administration - must be limited by the demonstrated needs (and not only wishes) of clients, and a preliminary differentiated analysis of capacities of an authority and the public administration in general. 
Polona Kovač

Tax Procedure Law within the Reduction of

Administrative Burdens - between Goals and Praxis

Even more important is the realisation that the data employed is not the only relevant one for a cumulative evaluation, as individual regulatory rules produce complex combined effects working either in the same or opposed directions, so that their projected positive effects may even synergically intensify each other (like in the service of provisional specifications by regular mail), or they cancel each other out. Even some abolished obligations of those involved in proceedings (e.g. notification of debtors before enforcement is initiated) are therefore worthy of consideration whether, on account of their established positive effects, they might be reintroduced into the applicable system. The majority of the considered institutes - primarily the system of stating personal income tax, service by regular mail, and special cases of cancellation, deferral or phased payment of tax due -, on the other hand, may be assessed as suited to the social reality and the ambition to modernise the Slovenian public administration.

Dr. Polona Kovač received a doctoral degree in 2005 from the Faculty of Law in Ljubljana. In 2001 she began to work full time at the Faculty of Administration where today, holding the rank of Assistant Professor, she is in charge of several Public Administration courses of the first and second cycles, while also teaching at several other faculties. Since the late 1990s she has continuously conducted different seminars and workshops, and presented and published papers at conferences in Slovenia and abroad. In recent years she has also been engaged as an appraiser and juror in the Slovenian Business Excellence Prize award, evaluator in quality evaluation procedures for higher education study programmes and institutions, member of the Senate of the Faculty of Administration, member of the governmental Strategic Council for the Public Sector, and president of the Council of Officials. 


\section{Literature in viri:}

- Androjna, V., \& Kerševan, E. (2006). Upravno procesno pravo. Ljubljana: GV Založba.

- Ferlinc, A. (2009). Razmerje med kazenskim in davčnim postopkom - privilegij zoper samoobtožbo. Ljubljana: Pravnik, vol. 64, no. 1-2, 25-56.

- Government of the Republic of Slovenia: Reform Programme for Achieving the Lisbon Strategy Goals. October 2008. Retrieved 30 Sept.2009, from : http://www.umar.gov.si/fileadmin/user_upload/projects/04_alizb-strategija.pdf

- Hren, B. (2009). Podjetja "zasula" Durs z vlogami za odlog plačila davkov. Dnevnik, 9 April, 2009, 17.

- Jerovšek, T. (1999). Zakon o splošnem upravnem postopku (ZUP) z uvodnimi pojasnili. Ljubljana: Uradni list RS.

- Jerovšek, T. (2005). Kakšni inštituti lahko omogočijo hiter in učinkovit davčni postopek. XII. Dnevi slovenske uprave. Portorož (11 pp.). Ljubljana: Faculty of Administration.

- Jerovšek, T. (2005a). Nekatere sugestije za drugačno ureditev davčnega postopka. Javna uprava (2/3), 286-299.

- Jerovšek, T., et al. (2008). Zakon o davčnem postopku s komentarjem. Ljubljana \& Maribor: Tax Education Institute \& Tax and Finance Research Institute.

- Jerovšek. T., \& Kovač, P. (2008). Posebni upravni postopki. Ljubljana: Faculty of Administration.

- Josevski, D. (2008). Slovenski program odprave administrativnih ovir s posebnim poudarkom na poenostavljanju upravnih postopkov. Podjetje in delo (6/7), 1339-1349.

- $\quad$ Klun, M. (2009). Pre-filled Income Tax Returns: Reducing Compliance Costs for Personal Income Tax Payers in Slovenia. Financ. theory pract., vol. 33, no. 2, 219-233.

- Kopp, F. O., \& Ramsauer, U. (2003). Verwaltungsverfahrensgesetz. Munich: Beck.

- Kovač, P. (2006). Nov koncept davčnega postopka - izbrana vprašanja. In Vladne reforme in javni sektor ter predsedovanje Slovenije Evropski uniji (ed. Setnikar-Cankar, S.). Ljubljana: Faculty of Administration.

- Kovač, P. (2006a). Postopkovna vprašanja davčnega inšpekcijskega nadzora. Javna uprava (2/3), 273-296.

- Kovač, P. (2007). The development of tax procedures in Slovenia. In Trends in development of public administration in South East Europe (ed. Vintar, M., \& Kovač, P.). Upravna misel. Ljubljana: Faculty of Administration \& NISPAcee, 153-172.

- Kovač, P. (2008). Vročanje v upravnem postopku (od vročitve upravne odločbe do njene izvršitve). Podjetje in delo (6/7), 1302-1316. 


\section{Polona Kovač}

Tax Procedure Law within the Reduction of

Administrative Burdens - between Goals and Praxis

- $\quad$ Pirnat, R. (ed. in chief) et al. (2004). Komentar zakonov s področja uprave ŠZJU, ZDU-1, ZSPJS, ZJA, ZINĆ. Ljubljana: Institute of Public Administration at the Faculty of Law of the University of Ljubljana.

- Predlog Zakona o davčnem postopku (ZDavP-2). Poročevalec DZ RS, no. 99/06 (20 Sept., 2006).

- Predlog zakona o spremembah in dopolnitvah zakona o davčnem postopku (ZDavP-2A). Poročevalec DZ RS, no. 127/08 (19 Dec., 2008).

- Silvani, C., \& Baer, C. (1997). Designing a Tax Administration Reform Strategy, Experiences and Guidelines. IMF Working Paper, WP/97/30. Washington: IMF.

- Šinkovec, J., \& Tratar, B. (2002). Zakon o davčnem postopku s komentarjem. Lesce: Oziris.

- Šturm, L. (ed.), et al. (2002). Komentar Ustave Republike Slovenije. Brdo: The Graduate School of Government and European Studies.

- Tax Administration of the Republic of Slovenia. (n.d.). Retrieved 30 Sept., 2007, from : http://www.durs.gov.si/ 